\title{
Pengaruh Persepsi Kegunaan, Kemudahan Penggunaan dan Norma Subyektif pada Minat Berperilaku Penggunaan E-Billing
}

\author{
Ni Made Dwi Ratnadi ${ }^{1}$ \\ Anak Agung Gde Putu Widanaputra ${ }^{2}$ \\ ${ }^{1.2}$ Fakultas Ekonomi dan Bisnis, Universitas Udayana, Indonesia \\ email:dwiratnadi@unud.ac.id
}

DOI: https://doi.org/10.24843/JIAB.2019.v14.i02.p03

\section{Jurnal Ilmiah Akuntansi dan Bisnis (JIAB)}

https://ojs.unud.ac.id/index.php/jiab/ user/profile

Volume 14

Nomor 2

Juli 2019

Halaman 169-182

p-ISSN 2302-514X

e-ISSN $\underline{2303-1018}$

\section{INFORMASI ARTIKEL}

Tanggal masuk:

21 Maret 2019

Tanggal revisi:

28 Mei 2019

Tanggal terima:

17 Juni 2019

\begin{abstract}
ABSTRAK
Penelitian bertujuan menguji secara empiris perilaku wajib pajak orang pribadi dalam penggunaan $e$-billing. Penelitian dilakukan pada Kantor Pelayanan Pajak Pratama di Provinsi Bali. Data dikumpulkan melalui metode survei. Sampel ditentukan dengan metode nonprobability sampling dengan teknik convenience sampling. Jumlah responden yang dianalisis sebanyak 160 orang. Teknik analisis data menggunakan structural equation modeling (SEM) berbasis variance dengan proses perhitungan dibantu aplikasi partial least square (PLS). Hasil analisis menunjukkan bahwa persepsi kegunaan berpengaruh positif pada sikap berperilaku, kemudahan penggunaan berpengaruh positif pada sikap terhadap menggunakan $e$-billing, kemudahan penggunaan berpengaruh positif pada persepsi kegunaan. Sikap berperilaku dan norma subyektif berpengaruh positif pada minat wajib pajak orang pribadi menggunakan $e$-billing system dalam pembayaran pajaknya.
\end{abstract}

Kata kunci: E-billing, persepsi kegunaan, kemudahan penggunaan, sikap

\section{Effects of Perceived Usefulness, Ease of Use and Subjective} Norms, on the Interest in E-Billing

\begin{abstract}
This study aims to examine the behavior of individual taxpayers that use ebilling. The study was conducted at the Primary Tax Office in the Province of Bali. Data was collected using surveys. The sample was selected using convenience non-probability sampling technique. The number of respondents analyzed was 120 people. A variance based structural equation modeling approach with the calculation process supported by the partial least square was used in data analysis. The results show that perceived usefulness has a positive effect on attitude toward using e-billing, ease of use has a positive effect on attitude toward e-billing, ease of use has a positive effect on the perceived usefulness. The attitude and subjective norms positively influence the interest of individual taxpayers in using the e-billing system in paying taxes. Keyword: E-billing, perceived ease of used, usefulness, attitude
\end{abstract}

\section{PENDAHULUAN}

Pajak merupakan salah satu sumber penerimaan Negara. Pajak berperan sangat penting untuk menyejahterakan masyarakat. Begitu pentingnya peran pajak maka diharapkan kesadaran dan kepatuhan seluruh rakyat Indonesia untuk melakukan kewajiban perpajakan. Khususnya, bagi mereka yang memiliki penghasilan sesuai ketentuan aturan perpajakan untuk turut berperan dalam memenuhi kewajibannya kepada Negara. Perilaku ketidak patuhan masyarakat terhadap kewajiban perpajakan disebabkan oleh kurangnya pengetahuan teknis perpajakan dan menganggap sistem perpajakan sangat kompleks dan cenderung menyulitkan masyarakat (Saad, 2014).

Dewasa ini wajib pajak (WP) dapat lebih mudah dalam pemenuhan kewajiban perpajakan dengan memanfaatkan fasilitas-fasilitas elektronik yang telah 
disediakan oleh Direktorat Jenderal Pajak (DJP). Salah satu fasilitas tersebut adalah sistem pembayaran elektronik (billing system atau $e$ billing). Aplikasi $e$-billing yang mulai berlaku efektif per 1 Juli 2016, menjamin keamanan transaksi elektronik antara wajib pajak dan DJP. Aplikasi ini menawarkan kemudahan pembayaran pajak secara elektronik dengan segala kelebihan antara lain mudah, cepat,dan akurat (Susanti, 2017).

Penggunaan e-billing yang berbasis internet, diduga menyebabkan pengguna mempertimbangkan manfaat dan kegunaan sistem tersebut. Pernyataan ini didasari oleh Theory of Reaseond Action (TRA) yang dikemukan Ajzen dan Fisbein (1980). TRA menyatakan bahwa seseorang akan menerima komputer jika komputer memberikan manfaat kepada para pemakainya. Sanjaya (2005) menyatakan bahwa berdasarkan TRA, penggunaan internet ditentukan oleh persepsi individu dan sikap yang pada akhirnya akan membentuk perilaku seseorang dalam penggunaan suatu teknologi informasi (internet). Berdasarkan pernyataan Sanjaya (2005), persepsi para pengguna $e$-billing akan memengaruhi perilakunya. Penelitian tentang minat berperilaku (behavioral intention) dalam penggunaan teknologi dapat dijelaskan dengan menggunakan Technology Acceptence Model (TAM) yang dikemukan oleh Davis (1989). Kegunaan persepsian (perceived usefulness) atau rasa manfaat dan kemudahan penggunaan persepsian (perceived ease of use) terhadap minat perilaku (behavioral intention) atau intensitas penggunaan teknologi informasi merupakan konsep yang mendasari TAM.

Ada dua konsep utama yang dipercaya dalam user acceptance yaitu perceived usefulness dan perceived ease of use (Venkatesh \& Moris, 2000). Manfaat (perceived usefulness) didefinisikan sebagai tingkat kepercayaan seseorang bahwa penggunaan suatu sistem informasi meningkatkan kinerja dalam pekerjaannya. Kemudahan (perceived ease of use) merupakan tingkat kepercayaan seseorang bahwa penggunaan teknologi sistem informasi mudah dan tidak membutuhkan usaha yang keras. Apabila dikaitkan dengan penggunaan $e$ billing, wajib pajak dapat menggunakan teknologi ini untuk membayar pajak secara terus-menerus. Rendahnya penggunaan teknologi informasi dapat menyebabkan rendahnya return dari investasi organisasi dalam teknologi informasi (Venkatesh dan Davis, 2000; Arthana \& Rukhviyanti, 2015) dalam penelitian ini, manfaat yang optimal tidak diperoleh oleh pemerintah.
Sistem e-billing sudah ditetapkan sejak tahun 2014 dan baru berlaku efektif bulan Juli 2016. Adapun tujuan khusus penelitian adalah untuk membuktikan secara empiris pengaruh rasa manfaat, kemudahan penggunaan pada sikap wajib pajak orang pribadi dalam penggunaan e-billing. Pengaruh sikap berperilaku dan norma subjektif pengguna pada minat perilaku wajib pajak orang pribadi dalam penggunaan e-billing. Penelitian ini penting dilakukan untuk mengkonfirmasi teori TAM yang diterapkan pada perilaku penggunaan e-billing oleh WPOP dalam pembayaran pajak.

Penelitian tentang minat berperilaku (behavioral intention) dalam penggunaan teknologi dengan menggunakan Technology Acceptence Model (TAM), menawarkan suatu penjelasan yang kuat dan sederhana untuk penerimaan teknologi dan perilaku para penggunanya (Venkatesh \& Morris, 2000). Model TAM dilandasi oleh theory of reaseond action (TRA) yang dikemukan Ajzen \& Fishbein (1980). TRA menyatakan bahwa seseorang menerima komputer jika komputer memberikan manfaat kepada para pemakainya. Berdasarkan TRA, penggunaan $e$-billing ditentukan oleh persepsi individu dan sikap yang akhirnya membentuk perilaku seseorang dalam penggunaan suatu teknologi informasi (e-billing).

Technology acceptance model (TAM) merupakan salah satu teori tentang penggunaan sistem teknologi informasi yang dianggap sangat berpengaruh dan umumnya digunakan untuk menjelaskan penerimaan individual terhadap penggunaan sistem teknologi informasi. Davis (1989) menyatakan TAM merupakan model yang digunakan untuk memprediksi penerimaan pengguna teknologi berdasarkan dua variabel, yaitu perceived usefulness (persepsi kemanfaatan atau kegunaan) dan perceived ease of use (persepsi kemudahan penggunaan) mempengaruhi attitude toward behavior (sikap terhadap perilaku) individu dalam penggunaan teknologi informasi. Sikap terhadap perilaku selanjutnya akan menentukan perilaku dari individu tersebut apakah berniat menggunakan teknologi informasi (intention)

Task Technology Fit (TTF) dikembangkan oleh Goodhue \& Thompson (1995). TTF adalah suatu tingkat individu merasakan teknologi membantu pelaksanaan tugas-tugasnya atau tugas jabatan. Secara lebih spesifik TTF merupakan penyesuaian antara kebutuhan teknologi dalam melaksanakan tugas-tugas, kemampuan individu dan fungsi teknologi. Prioritas TTF adalah interaksi antara tugas, 
teknologi dan individu. Berbagai macam tugas yang pasti membutuhkan berbagai macam fungsi teknologi yang pasti. Model ini mengindikasikan bahwa kinerja akan meningkat ketika sebuah teknologi menyediakan fitur dan dukungan yang tepat dikaitkan dengan tugas. TTF dalam penelitian ini adalah interaksi wajib pajak sebagai individu pengguna, e-billing sebagai sebuah teknologi informasi dan kaitannya dengan fungsi tugas penyetoran atau pembayaran pajak yang harus dilakukan oleh wajib pajak. Sistem e-billing yang memiliki fungsi sebagai sarana pembayaran pajak dapat membantu kewajiban WP dalam membayar pajak secara mudah dan cepat. TTF dianggap sebagai kemampuan learning management system (LMS) untuk mendukung individu dalam berbagai kegiatan belajar dan terlibat dalam mengakomodasi berbagai kemampuan (Zadeh et al, 2014). Penggunaan sistem elektronik dapat memudahkan perhitungan yang dilakukan secara cepat dan tepat dalam melaporkan pajak dengan menggunakan sistem komputer sehingga dapat memberikan kemudahan (Rysaka et al,, 2013).

Jogiyanto (2007) menyatakan bahwa norma subjektif sebagai persepsi atau pandangan seseorang terhadap kepercayaan-kepercayaan orang lain yang akan mempengaruhi minat untuk melakukan atau tidak melakukan perilaku yang sedang dipertimbangkan. Ajzen (1988) mendefinisikan norma subjektif sebagai persepsi seseorang mengenai tekanan sosial untuk melakukan atau tidak melakukan perilaku. Norma subjektif mengacu pada penilaian subjektif individu mengenai preferensi orang lain dan dukungan (support) atas suatu perilaku.

Seseorang akan memiliki keinginan terhadap suatu objek atau perilaku seandainya terpengaruh oleh orang-orang disekitarnya untuk melakukannya atau menyakini bahwa lingkungan atau orang-orang disekitarnya mendukung terhadap apa yang dilakukannya (Mas'ud, 2012). Norma subjektif dapat dipengaruhi oleh faktor eksternal seperti tekanan dari lingkungan sosial, kesempatan yang muncul, teman kerja, keamanan, praktik sosial dan waktu dalam memutuskan penggunaan sistem. Nysveen et al. (2005) mencatat bahwa norma sosial adalah variabel penting untuk menjelaskan keberhasilan penggunaan sistem. Sejak TRA dan TPB telah berhasil diterapkan dalam perilaku konsumen online, penerimaan teknologi dan penggunaan sistem (Ajzen \& Fishbein, 1980; Ajzen \& Fishbein, 1970) norma subjektif diusulkan sebagai variabel langsung dari niat perilaku dalam penelitian ini.

Ajzen \& Fishbein (1970) mendefinisikan sikap sebagai jumlah dari afeksi (perasaan) yang dirasakan seseorang untuk menerima atau menolak suatu obyek atau perilaku dan diukur dengan suatu prosedur yang menempatkan individual pada skala evaluatif dua kutub, misalnya baik atau jelek, setuju atau menolak, dan sebagainya. Sikap (attitude) adalah evaluasi kepercayaan atau perasaan positif maupun negatif dari seseorang jika harus melakukan perilaku yang akan ditentukan (Jogiyanto, 2007).

Sikap seseorang juga dapat dilihat dari kepercayaan seseorang untuk mau menggunakan sebuah sistem. Kepercayaan terhadap berbagai informasi dapat menghasilkan sikap yang baik oleh pengguna $e$-billing yang akan meningkatkan sikap secara tidak langsung (Arthana \& Rukhviyanti, 2015). Sikap berperilaku penggunaan diidentifikasi sebagai faktor yang menunjukkan perilaku masa depan atau penyebab munculnya niat menggunakan yang akhirnya menyebabkan menjadi sebuah faktor perilaku utama.

Minat atau intensi perilaku adalah keinginan untuk melakukan perilaku (Jogiyanto, 2007). Ajzen (1988) dan Taylor \& Todd (1995) menyatakan bahwa minat perilaku (behavior intention) menunjukkan keputusan seseorang untuk melakukan atau tidak melakukan suatu perilaku tertentu. Minat atau intensi berperilaku adalah keinginan untuk melakukan perilaku (Jogiyanto, 2007). Konsep minat perilaku menyatakan bahwa motivasi individu untuk terlibat dalam perilaku didefinisikan oleh sikap yang memengaruhi perilaku individu tersebut (Ajzen \& Fishbein, 1970).

Peterson (2003) menyatakan minat merupakan prediktor yang penting dari perilaku. Minat perilaku menunjukkan seberapa banyak usaha yang dilakukan individu untuk berkomitmen dalam melakukan suatu perilaku. Besarnya suatu komitmen mendefinisikan terwujudnya perilaku tersebut (Arthana \& Rukhviyanti, 2015). Minat dapat diukur dengan menggunakan norma subjektif dan sikap yang mempengaruh minat seseorang dalam bertindak sedangkan norma subjektif dipengaruhi oleh keyakinan dan motivasi apakah menginginkan orang lain untuk terlibat didalamnya.

Penelitian yang menggunakan modal TAM dalam penggunaan teknologi informasi sudah banyak dilakukan seperti: Adam et al. (1992), Chin \& Todd (1995), (Davis (1989, 1993), Igbaria et al. (1997), Segars \& Grove (1993), Subramanian (1994), Szajna (1996), Taylor \& Todd (1995), Venkatesh et al. (2000), Venkatesh \& Moris (2000), dan Sanjaya (2005). Akan tetapi, penelitian mengenai minat berperilaku menggunakan $e$-billing dengan model TAM masih relatif sedikit. E-billing merupakan 
aplikasi menggunakan internet untuk pembayaran pajak secara online. Fasilitas e-billing untuk membayar pajak digunakan oleh WPOP, e-billing sudah mulai efektif diberlakukan sejak bulan Juli 2016. Sistem ini juga memberikan kemudahan bagi wajib pajak untuk melakukan pembayaran pajak.

Pembayaran pajak dengan sistem e-billing dapat dilakukan dimana saja melalui sistem online dan real time. Hal ini membuat efisiensi biaya dan waktu bagi wajib pajak yang sebelumnya harus membayar pajak dengan terlebih dahulu membuat Surat Setoran Pajak (SSP) sebelum melakukan pembayaran di kantor pos atau bank persepsi lainnya. Direktorat jendral pajak menyatakan bahwa penggunaan e-billing memberikan manfaat bagi wajib pajak dalam melakukan pembayaran pajaknya kapan pun dan dimanapun dengan menggunakan Kode Billing (Susanti, 2017). Hubungan persepsi kemudahan kegunaan pada penggunaan senyatanya lebih kuat dibandingkan konstruk manapun (Davis,1989). Pernyataan Davis (1989), didukung oleh Szajna (1996) yang menemukan hubungan yang signifikan antara persepsi kegunaan dengan penggunaan sistem informasi. Demikian pula Igbaria et al. (1997) menemukan hal yang sama bahwa persepsi kegunaan berpengaruh pada penggunaan aktual. Berdasarkan hasil penelitian tersebut, dan manfaat e-billing bagi wajib pajak yang diharapkan oleh pemerintah, maka diajukan hipotesis penelitian seperti berikut ini.

$\mathrm{H}_{1}$ : Persepsi kegunaan berpengaruh positif pada sikap WPOP dalam menggunakan e-billing.

TAM merupakan model yang digunakan untuk memprediksi penerimaan pengguna pada teknologi salah satunya berdasarkan persepsi kemudahan. Jadi dengan individu menganggap bahwa suatu sistem teknologi mudah untuk digunakan maka hal tersebut mendorong individu untuk menggunakan teknologi tersebut. Studi yang dilakukan Laihad (2013) menunjukkan hasil bahwa persepsi kemudahan berpengaruh pada kegunaan teknologi e-filing. Nurhasanah et al. (2015) dengan hasil penelitiannya persepsi kemudahan penggunaan berpengaruh pada penggunaan e-filling. Kemudahan pengguna mempengaruhi penggunaan sistem. Jika pengguna menginterpretasikan bahwa sistem mudah digunakan maka penggunaan sistem tercapai. E-billing merupakan sistem untuk membantu wajib pajak membuat surat setoran elektronik dan mendapatkan kode billing untuk membayar pajak. Kemudahan pembayaran pajak yang ditawarkan dengan basis teknologi seperti e-billing diharapkan mampu mengubah stigma wajib pajak mengenai pembayaran pajak yang sulit dan memerlukan waktu yang lama. Berdasarkan hasil penelitian dan uraian tersebut, maka diajukan hipotesis penelitian seperti berikut ini. $\mathrm{H}_{2}$ : Kemudahan penggunaan berpengaruh positif pada sikap WPOP dalam menggunakan $e$ billing

Keputusan yang dilakukan oleh individu untuk menerima suatu teknologi sistem informasi merupakan tindakan sadar yang dapat dijelaskan dan diprediksi oleh minat perilakunya. TAM berargumentasi bahwa penerimaan individual terhadap sistem teknologi informasi ditentukan oleh perceived of usefulness dan perceived easy of used. Kemudahan penggunaan memengaruhi rasa manfaat, akan tetapi tidak sebaliknya. Pemakai sistem akan menggunakan sistem jika dirasakan bermanfaat, baik sistem itu mudah digunakan ataupun tidak mudah digunakan. Sistem yang sulit digunakan, tetap digunakan jika pemakainya merasa bahwa sistem bermanfaat. Pemakaian sistem dapat bersifat sukarela atau bersifat wajib. Pemakaian e-billing bagi WPOP bersifat sukarela sehingga dapat merefleksikan persepsi dan perasaan masing-masing individual dan menjadi penentu yang baik dari kesulitan sistem. Penelitian sebelumnya menguji pengaruh persepsi kemudahaan penggunaan terhadap prsepsi rasa manfaat dilakukan oleh Bashir \& Madhavaiah (2015) menunjukkan bahwa terdapat pengaruh positif dan signifikan persepsi kemudahaan penggunaan terhadap persepsi rasa manfaat. Hasil yang berbeda ditunjukkan oleh penelitian yang dilakukan oleh Chen \& Tsai (2007), menyatakan bahwa persepsi kemudahaan penggunaan tidak berpengaruh signifikan terhadap minat penggunaan aplikasi mobile tourisme. Billing system merupakan sistem yang menerbitkan kode billing untuk pembayaran atau penyetoran penerimaan negara secara elektronik. Sistem e-billing membimbing pengguna mengisi SSP elektronik dengan tepat dan benar sesuai dengan transaksi yang ingin dituntaskan. E-billing hadir memberikan kemudahan dalam pembayaran pajak pada wajib pajak. Berdasarkan hal tersebut, hipotesis yang dapat diajukan dalam penelitian ini adalah:

$\mathrm{H}_{3}$ : Kemudahan penggunaan $e$-billing berpengaruh positif pada persepsi kegunaan WPOP dalam menggunakan e-billing.

Ajzen (1988) mendefinisikan norma subjektif sebagai persepsi seseorang mengenai tekanan sosial untuk melakukan atau tidak melakukan perilaku. Norma subjektif mengacu pada penilaian subjektif 
individu mengenai preferensi orang lain dan dukungan (support) atas suatu perilaku. Berbagai studi empiris yang mengkaji konstruk norma subjektif dalam penelitian terkait teknologi informasi telah dilakukan oleh para peneliti sebelumnya. Penelitian sebelumnya yang dilakukan oleh Mas'ud (2012) menunjukkan bahwa norma subjektif berpengaruh positif terhadap minat nasabah menggunakan sistem pembayaran dengan ATM. Seni dan Ratnadi (2017) membuktikan bahwa norma subyektif berpengaruh pada minat perilaku investasi.

$\mathrm{H}_{4}$ : Persepsi norma subjektif berpengaruh positif pada minat perilaku WPOP menggunakan $e$ billing.

Sikap (attitude) didefinisikan sebagai perasaan positif atau negatif seseorang untuk melakukan perilaku tertentu (Davis, 1989). Kepercayaan terhadap berbagai informasi akan menghasilkan sikap yang baik oleh pengguna $e$-billing yang akan meningkatkan sikap secara tidak langsung. Dalam penelitian ini konstruk sikap diartikan sebagai perasaan positif atau negative pengguna e-billing yang ditunjukkan oleh perasaan suka atau tidak suka seseorang terhadap e-billing (Arthana \& Rukhviyanti, 2015). Nasri \& Lanouar (2012) menunjukan hubungan yang signifikan antara sikap dan minat menggunakan internet banking. Berbeda dengan penelitian yang dilakukan oleh peneliti sebelumnya, Taylor \& Todd (1995) menyebutkan bahwa sikap tidak memiliki pengaruh terhadap minat perilaku untuk kedua grup pengguna, baik grup yang berpengalaman maupun yang tidak berpengalaman. Apabila seseorang memiliki sikap positif terhadap $e$ billing, maka individu tersebut akan berminat menggunakannya. Hipotesis 5 dikembangkan seperti berikut ini.

$\mathrm{H}_{5}$ : Sikap berperilaku pengguna berpengaruh positif pada minat perilaku WPOP menggunakan $e$ billing

\section{METODE PENELITIAN}

Penelitian ini dilakukan di provinsi Bali. Subyek penelitian adalah wajib pajak orang pribadi (WPOP) yang terdaftar di Kantor Pelayanan Pajak (KPP) Pratama Denpasar Barat, KPP Pratama Denpasar Timur, KPP Pratama Badung Selatan, KPP Pratama Badung Utara, KPP Pratama Gianyar, KPP Pratama Tabanan, dan KPP Pratama Singaraja. Alasan penelitian ini dilakukan di provinsi Bali, karena dari 500.971 WPOP baru sebanyak 23,5 persen menggunakan $e$-billing pada laporan pajak tahun 2016 (sumber: Kanwil DJP Bali, 2017). Hal ini menunjukkan bahwa kebanyakan WPOP masih memilih sistem pembayaran secara manual dengan SSP.

Variabel penelitian dapat diidentifikasikan seperti berikut; kemudahaan penggunaan $\left(\mathrm{X}_{1}\right)$, rasa manfaat $\left(\mathrm{X}_{2}\right)$, norma subjektif $\left(\mathrm{X}_{3}\right)$, sikap berperilaku pengguna $\left(\mathrm{Y}_{1}\right)$, dan minat berperilaku WPOP dalam menggunakan e-billing $\left(\mathrm{Y}_{2}\right)$. Berdasarkan identifikasi variabel dan hipotesis, maka dapat digambarkan model penelitian seperti Gambar 1 .

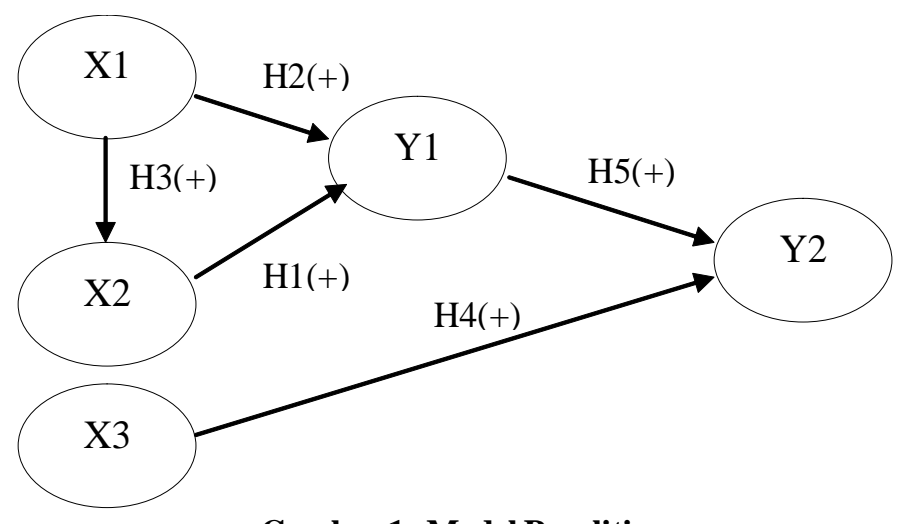

Sumber: Data Diolah (2018)

Gambar 1. Model Penelitian

Variabel kemudahaan penggunaan $\left(\mathrm{X}_{1}\right)$ adalah persepsi WPOP atas penggunaan e-billing, didefinisikan sebagai suatu tingkat kepercayaan seseorang bahwa menggunakan teknologi e-billing tersebut tak perlu bersusah payah. Indikator kemudahaan penggunaan diadopsi dari Ratnaningrum
(2013) dan dimodifikasi sesuai dengan objek penelitian yakni mudah dipelajari $\left(\mathrm{X}_{1.1}\right)$ adalah penilaian bahwa penggunaan $e$-Billing mudah untuk dipelajari. Penggunaannya fleksibel $\left(\mathrm{X}_{1.2}\right)$ adalah penilaian bahwa penggunaan $e$-Billing fleksibel. Mudah untuk dikuasai $\left(\mathrm{X}_{1.3}\right)$ adalah penilaian bahwa penggunaan 
e-Billing mudah untuk dikuasai. Mudah dimengerti $\left(\mathrm{X}_{1.4}\right)$ adalah penilaian bahwa penggunaan $e$-Billing dirasa mudah untuk dimengerti. Secara keseluruhan penggunaanya mudah $\left(\mathrm{X}_{1.5}\right)$ adalah penilaian bahwa secara keseluruhan penggunaan $e$-Billing mudah untuk digunakan.

Rasa manfaat atau kegunaan persepsian $\left(\mathrm{X}_{2}\right)$ adalah persepsi WPOP atas kebermanfaatan adalah tingkatan dimana pengguna percaya bahwa dengan menggunakan teknologi atau sistem akan meningkatkan performa WPOP dalam membayar pajak dan berhubungan dengan manfaat yang diterima WPOP. Indikator rasa manfaat diadopsi dari Ratnaningrum (2013) dan dimodifikasi sesuai dengan objek penelitian yakni memudahkan transaksi pembayaran pajak $\left(\mathrm{X}_{2.1}\right)$ adalah penilaian bahwa penggunaan e-Billing dapat membantu mempermudah pekerjaan WPOP dalam membayar pajak. Efektif $\left(\mathrm{X}_{2.2}\right)$ adalah penilaian bahwa penggunaan $e$-Billing tepat guna sehingga menghemat waktu. Bermanfaat secara keseluruhan $\left(\mathrm{X}_{2.3}\right)$ adalah penilaian bahwa secara keseluruhan penggunaan $e$-Billing bermanfaat.

Norma subjektif $\left(\mathrm{X}_{3}\right)$ mengacu pada penilaian subjektif individu mengenai preferensi orang lain dan dukungan (support) atas suatu perilaku menggunakan $e$-Billing. Indikator norma subjektif diadopsi dari Mas'ud (2012) dan dimodifikasi sesuai dengan waktu dan objek penelitian yakni pengaruh teman $\left(\mathrm{X}_{3.1}\right)$ adalah penilaian bahwa pengaruh teman dianggap penting memengaruhi WPOP untuk menggunakan e-Billing. Pengaruh keluarga $\left(\mathrm{X}_{3.2}\right)$ adalah penilaian bahwa pengaruh keluarga dianggap penting memengaruhi WPOP untuk menggunakan $e$-billing. Pengaruh pihak lain yang dianggap penting $\left(\mathrm{X}_{3.3}\right)$ adalah penilaian bahwa pengaruh pihak lain dianggap penting memengaruhi WPOP untuk menggunakan e-billing.

Sikap $\left(\mathrm{Y}_{1}\right)$ menurut Ajzen \& Fishbein (1970) adalah jumlah dari afeksi (perasaan) yang dirasakan seseorang untuk menerima atau menolak suatu obyek atau perilaku dan diukur dengan suatu prosedur yang menempatkan individual pada skala evaluasi dua kutub, misalnya baik atau jelek: setuju atau menolak, dan lainnya. Sikap terhadap penggunaan sistem yang berbentuk penerimaan atau penolakan sebagai dampak bila seseorang menggunakan e-Billing. Indikator sikap berperilaku pengguna diadopsi dari Nasri \& Lanouar (2012) dan dimodifikasi sesuai objek penelitian yakni ide yang bagus $\left(\mathrm{Y}_{1.1}\right)$ adalah penilaian bahwa penggunaan $e$-Billing merupakan ide yang bagus. Ide yang bijaksana $\left(\mathrm{Y}_{12}\right)$ adalah penilaian bahwa penggunaan $e$-Billing merupakan ide yang bijaksana. Menyenangkan untuk digunakan $\left(\mathrm{Y}_{13}\right)$ adalah penilaian bahwa penggunaan $e$-Billing merupakan hal yang menyenangkan untuk dilakukan. Merasa perlu menggunakan $\left(\mathrm{Y}_{1.4}\right)$ adalah penilaian bahwa e-Billing merupakan hal yang dirasa perlu untuk digunakan.

Konsep minat perilaku $\left(\mathrm{Y}_{2}\right)$ menyatakan bahwa motivasi individu untuk terlibatdalam perilaku didefinisikan oleh sikap yang memengaruhi perilaku individu dalam menggunakan e-Billing. Indikator minat perilaku diadopsi dari Nasri \& Lanouar (2012) serta dimodifikasi sesuai dengan tempat dan objek penelitian yakni keinginan untuk menggunakan sesuai kebutuhan $\left(\mathrm{Y}_{2.1}\right)$ adalah penilaian bahwa pengguna berkeinginan menggunakan $e$-Billing sesuai dengan kebutuhan untuk membayar pajak. Kepercayaan mengerjakan pekerjaan menggunakan sistem $\left(\mathrm{Y}_{2.2}\right)$ adalah penilaian bahwa pengguna memiliki kepercayaan dalam menggunakan e-Billing untuk membayar pajak.

Jenis data yang digunakan dalam penelitian ini adalah data kuantitatif dan data kualitatif. Data kuantitatif adalah data dalam bentuk angka-angka yang berasal dari perhitungan masing-masing atribut pengukuran variabel. Sedangkan data kualitatif adalah jenis data yang berupa penjelasan atau hasil jawaban kuesioner, yang diboboti dengan angkaangka sesuai dengan skala pengukuran yang digunakan (Chandrarin, 2018:122). Data kuantitatif dalam penelitian ini berupa jumlah wajib pajak orang pribadi yang terdaftar KPP Pratama di Bali. Data kualitatif adalah jawaban responden atas kuesioner diukur dengan skala Likert yang diberikan bobot 1 sampai 5. Sumber data adalah data primer. Data primer yaitu data yang berasal langsung dari objek penelitian atau responden, baik individu maupun kelompok (Chandrarin, 2018:123). Metode survei digunakan untuk mengumpulkan data primer, dengan instrumen berupa kuesioner yang dijawab oleh responden.

Populasi adalah seluruh WPOP yang telah menggunakan e-billing yaitu sebanyak 141.279 orang. Metode pengambilan sampel dengan convenience sampling. Rahyuda (2016:145) menyatakan bahwa convenience sampling merupakan metode pengambilan sampel yang dilakukan dengan memilih sampel dari elemen populasi (orang atau kejadian) yang datanya mudah diperoleh peneliti atau peneliti memiliki kebebasan untuk memilih sampel yang paling cepat dan murah. Sekaran (2006:160) menyatakan bahwa dalam penelitian multivariat (termasuk analisis regresi berganda) ukuran sampel sebaiknya beberapa kali 
dari jumlah variabel, minimal 10 kali atau lebih besar dari jumlah variabel dalam studi. Sebagai aturan umum, ukuran sampel direkomendasikan dengan rasio 10:1 atau 20-1 kasus untuk setiap variabel (Hair et al, 2006:98-99). Oleh karena jumlah keseluruhan indikator dalam penelitian adalah 17 maka jumlah parameter sampel yang digunakan dengan estimasi sebanyak 170-240 responden. Namun dalam penelitian ini jumlah kuesioner disebarkan untuk sebanyak 200 reponden.

Penelitian ini menggunakan uji partial least square (PLS) untuk analisis data. PLS merupakan model analisis yang powerful karena dapat diterjemahkan dalam semua data, ukuran sampel tidak terlalu besar, dan digunakan untuk konfirmasi teori, serta digunakan untuk membangun hubungan yang belum ada landasan teorinya (Solimun, 2002:23). PLS adalah analisis persamaan structural (SEM) berbasis varian, secara simultan dalam melakukan pengujian model pengukuran dan pengujian model structural. Tujuan PLS adalah memprediksi pengaruh variabel $\mathrm{X}$ terhadap variabel $\mathrm{Y}$ dan menjelaskan hubungan teoritis diantara kedua variabel (Jogiyanto, 2007).

\section{HASIL DAN PEMBAHASAN}

Jumlah Kantor Pelayanan Pajak (KPP) Pratama yang ada di Bali sebanyak tujuh buah. Tercatat 141.279 Wajib Pajak Orang Pribadi yang menggunakan e-billing. Berdasarkan jumlah populasi, ditentukan sebanyak 200 responden. Berdasarkan jumlah sampel tersebut, kemudian ditentukan responden untuk tiap-tiap KPP Pratama secara proporsional.

Instrumen penelitian sebelum disebarkan diuji validitas dan reliabilitas. Kuesioner diujikan pada 40 orang mahasiswa Sarjana Akuntansi Fakultas Ekonomi dan Bisnis Universitas Udayana, yang sudah menempuh mata kuliah Perpajakan, dengan pertimbangan mahasiswa sudah mengetahui cara penggunaan $e$-billing. Uji validitas digunakan untuk mengukur valid tidaknya suatu kuesioner. Pengujian validitas dilakukan dengan menghitung korelasi antara skor tiap-tiap butir pertanyaan dan skor total. Uji validitas dilakukan dengan melihat nilai pearson correlation. Nilai koefisien yang positif dan lebih besar dari 0,3 mengindikasikan bahwa indikator tersebut valid. Tabel 1 menyajikan hasil uji validitas kuesioner penelitian sebelum disebarkan.

Tabel 1. Hasil Uji Validitas Kuesioner

\begin{tabular}{lccc}
\hline \multicolumn{1}{c}{ Variabel } & Instrumen & Pearson Correlation & Keterangan \\
\hline \multirow{2}{*}{ Kemudahan penggunaan } & X1.1 & 0,905 & Valid \\
(X1) & X1.2 & 0,951 & Valid \\
& X1.3 & 0,848 & Valid \\
& X1.5 & 0,856 & Valid \\
Persepsi kegunaan & X2.1 & 0,915 & Valid \\
(X2) & X2.2 & 0,887 & Valid \\
& X2.3 & 0,924 & Valid \\
Norma subyektif & X3.1 & 0,839 & Valid \\
(X3) & X3.2 & 0,861 & Valid \\
Sikap berperilaku pengguna & X3.3 & 0,914 & Valid \\
(Y1) & Y1.1 & 0,841 & Valid \\
& Y1.2 & 0,925 & Valid \\
Minat berperilaku (Y2) & Y1.4 & 0,872 & Valid \\
& Y2.1 & 0,818 & Valid \\
& Y2.2 & 0,790 & Valid \\
\hline
\end{tabular}

Sumber: Data diolah, 2018

Berdasarkan hasil uji validitas, seluruh variabel dikatakan valid karena nilai pearson correlation lebih dari 0,3. Hasil analisis reliabilitas atau keandalan instrumen menunjukkan sejauh mana suatu pengukuran dapat memberikan hasil yang konsisten bila dilakukan pengukuran kembali. Variabel dikatakan reliabel apabila nilai croncbach's alpha> 0,70 . Tabel 2 menyajikan hasil uji reliabilitas sebelum kuesioner diujikan kepada responden sesungguhnya.
Pengumpulan data dilakukan dengan menemui secara langsung responden yang sedang melaporkan pajaknya di tujuh buah KPP Pratama yang ada di Provinsi Bali dari bulan Maret sampai tanggal 20 Juli 2018. Tanggal 20 Juli merupakan tanggal menjelang batas terakhir pelaporan semua jenis PPh. Berdasarkan pertimbangan tersebut diharapkan dapat secara mudah dan cepat menemukan WPOP yang bersedia menjadi responden penelitian. 
Tabel 2. Hasil uji Reliabilitas Kuesioner

\begin{tabular}{lcc}
\hline \multicolumn{1}{c}{ Variabel } & Nilai Cronbach's Alpha & Keterangan \\
\hline Kemudahan penggunaan $\left(\mathrm{X}_{1}\right)$ & 0,935 & Reliabel \\
Persepsi kegunaan $\left(\mathrm{X}_{2}\right)$ & 0,848 & Reliabel \\
Norma subyektif $\left(\mathrm{X}_{3}\right)$ & 0,832 & Reliabel \\
Sikap berperilaku pengguna $\left(\mathrm{Y}_{1}\right)$ & 0,923 & Reliabel \\
Minat berperilaku $\left(\mathrm{Y}_{2}\right)$ & 0,917 & Reliabel \\
\hline
\end{tabular}

Sumber: Data dianalisis, 2018

Sebanyak 200 kuesioner disebarkan, diisi dan dikembalikan, akan tetapi hanya 160 (80 persen) yang responden meliputi usia, jenis kelamin, dan pekerjaan ditampilkan pada Tabel 3.

diisi secara lengkap dan dapat digunakan. Demografi

Tabel 3. Demografi Responden

\begin{tabular}{llcc}
\hline Keterangan & \multicolumn{1}{c}{ Keterangan } & Jumlah & Persentase $(\%)$ \\
\hline Usia & $21-30$ & 32 & 20 \\
& $31-40$ & 47 & 29 \\
& $41-50$ & 45 & 28 \\
& $51-60$ & 30 & 19 \\
Jenis Kelamin & $61-70$ & 5 & 3 \\
Pekerjaan & $71-80$ & 1 & 1 \\
& Laki-Laki & 87 & 54 \\
& Perempuan & 73 & 46 \\
& PNS & 38 & 24 \\
& Pengusaha & 52 & 33 \\
& Karyawan Swasta & 49 & 31 \\
& Profesional & 15 & 9 \\
& Lainnya & 6 & 4
\end{tabular}

Sumber: Data dianalisis, 2018

Model pengukuran dievaluasi untuk menguji validitas dan reliabilitas indikator-indikator yang digunakan untuk mengukur variabel laten. Ada empat model pengukuran yang sering digunakan yaitu evaluasi validitas konvergen, validitas diskriminan, reliabilitas komponen, dan reliabilitas komposit (Solimun, 2002). Tujuan pengujian validitas konvergen adalah untuk mengetahui apakah indikator yang digunakan mampu mendifiniskan atau merefleksikan sebuah variabel laten. Pedoman analisis yang digunakan adalah nilai outer loading yang lebih besar atau sama dengan 0,5 dan nilai tersebut signifikan pada $\alpha=5$ persen. Bila nilai outer loading tidak signifikan, model perlu direvisi dengan mengeluarkan indikator yang tidak memenuhi syarat, selanjutnya dianalisis kembali tanpa indikator yang tidak memenuhi syarat. Apabila nilai outer loading signifikan, berarti variabel tersebut merupakan pembentuk dari variabel laten yang digunakan. Hasil analisis model struktural disajikan pada Gambar 2. Hasil Analisis menunjukkan bahwa semua indikator memiliki nilai lebih besar dari $\alpha=5$ persen.

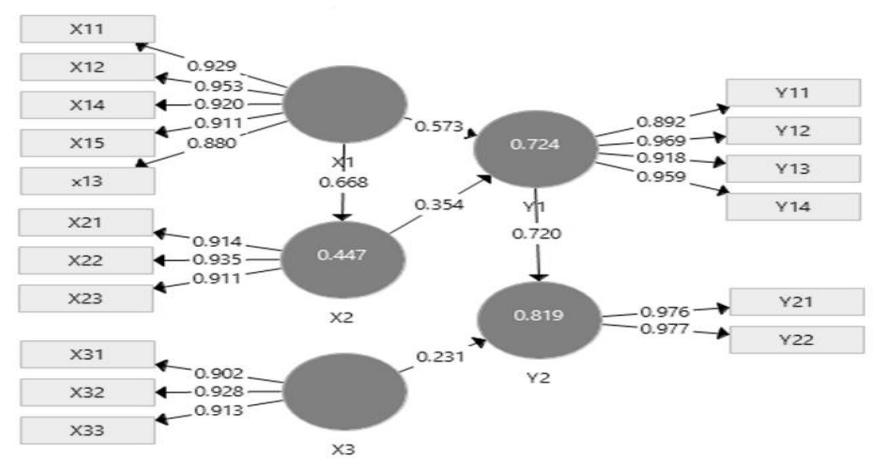

Sumber: Data diolah, 2018

\section{Gambar 2. Hasil Analisis Model Struktural}


Metode untuk menentukan validitas konstruk menggunakan average variance extracted (AVE) setiap variabel laten.Apabila nilai AVE lebih besar dari 0,5, maka validitas konstruk adalah baik. Hasil analisis disajikan pada Tabel 4. menujukkan nilai AVE variabel lebih besar dari 0,5 .

\section{Tabel 4. Nilai Average Variance Extracted (AVE)}

\begin{tabular}{ll}
\hline \multicolumn{1}{c}{ Variabel } & AVE \\
\hline Kemudahan penggunaan $\left(\mathrm{X}_{1}\right)$ & 0,845 \\
Persepsi kegunaan $\left(\mathrm{X}_{2}\right)$ & 0,846 \\
Norma subyektif $\left(\mathrm{X}_{3}\right)$ & 0,836 \\
Sikap berperilaku pengguna $\left(\mathrm{Y}_{1}\right)$ & 0,874 \\
Minat berperilaku $\left(\mathrm{Y}_{2}\right)$ & 0,953 \\
\hline
\end{tabular}

Sumber: Data diolah, 2018

yang membentuknya. Konstruk dikatakan reliabel apabila nilai composite reliability dan cronbach's

alpha-nya di atas 0,70 . Tabel 5 menyajikan hasil uji validitas.

Tabel 5. Hasil Uji Composite Reliability dan Cronbach's Alpha

\begin{tabular}{lcc}
\hline \multicolumn{1}{c}{ Variabel } & $\begin{array}{c}\text { Composite } \\
\text { Reliability }\end{array}$ & Cronbach's Alpha \\
\hline Kemudahan penggunaan $\left(\mathrm{X}_{1}\right)$ & 0.965 & 0,954 \\
Persepsi kegunaan $\left(\mathrm{X}_{2}\right)$ & 0,943 & 0,909 \\
Norma subyektif $\left(\mathrm{X}_{3}\right)$ & 0,939 & 0,903 \\
Sikap berperilaku pengguna $\left(\mathrm{Y}_{1}\right)$ & 0,965 & 0,952 \\
Minat berperilaku $\left(\mathrm{Y}_{2}\right)$ & 0.976 & 0,951 \\
\hline
\end{tabular}

Sumber: Data diolah,, 2018

Pengujian model struktural dilakukan dengan melihat besaran $\mathrm{R}^{2}$ yang merupakan uji goodness of fit

model. Pengujian inner model dapat dilihat dari nilai $\mathrm{R}^{2}$

Tabel 6. Hasil Uji $\mathbf{R}^{2}$

\begin{tabular}{lc}
\hline \multicolumn{1}{c}{ Variabel } & $\mathrm{R}^{2}$ \\
\hline Persepsi kegunaan $\left(\mathrm{X}_{2}\right)$ & 0,447 \\
Sikap berperilaku pengguna $\left(\mathrm{Y}_{1}\right)$ & 0,724 \\
Minat berperilaku $\left(\mathrm{Y}_{2}\right)$ & 0.819 \\
\hline
\end{tabular}

Sumber: Data diolah, 2018

Berdasarkan nilai $\mathrm{R}^{2}$ yang telah ditunjukkan seperti Tabel 6, maka nilai $\mathrm{Q}^{2}$ sebagai berikut:

$$
\begin{aligned}
\mathrm{Q} 2 & =1-(1-0,447)(1-0,724)(1-0,819) \\
& =1-(0,553)(0,276)(0,181) \\
& =1-0,027626 \\
& =0,972374
\end{aligned}
$$

Nilai $Q^{2}=0,972374$, menginterpretasikan bahwa model sangat baik yaitu mampu menjelaskan minat berperilaku sebesar 97,23 persen, sedangkan sisanya 2,87 persen dijelaskan oleh variabel lain. Hubungan antar variabel laten dalam penelitian ini diuji dengan lima hipotesis. Hasil pengujian hipotesis disajikan pada Tabel 7 dan Gambar 2.

Hipotesis pertama $\left(\mathrm{H}_{1}\right)$ menduga rasa manfaat berpengaruh positif pada Sikap berperilaku pengguna. Hasil ini ditunjukkan dengan hasil pengujian $H_{1}: \beta_{1}>0$, artinya pengaruh positif rasa manfaat pada sikap berperilaku pengguna. Hasil analisis menujukkan bahwa, koefisien regresi sebesar 0,354 dengan t hitung 2,886. Dengan menggunakan level of signifikan $\alpha=5$ persen maka t hitung lebih besar dari t tabel kritis 1,98. Artinya, rasa manfaat berpengaruh positif pada sikap berperilaku pengguna.

Hipotesis kedua $\left(\mathrm{H}_{2}\right)$ menduga kemudahan penggunaan berpengaruh positif pada Sikap berperilaku pengguna. Hasil pengujian menunjukkan bahwa $\mathrm{H}_{2}: \beta_{2}>0$, artinya kemudahan penggunaan berpengaruh positif pada Sikap berperilaku pengguna. Hasil analisis menunjukkan bahwa nilai koefisien 0,573 mempunyai besaran t hitung 4,352. Pada tingkat level of significance $\alpha=5$ persen maka t hitung lebih besar dari t tabel kritis 1,98. Artinya kemudahan penggunaan berpengaruh positif pada Sikap berperilaku pengguna. 
Tabel 7. Hasil Pengujian Hipotesis

\begin{tabular}{lcccc}
\hline \multicolumn{1}{c}{ Variabel } & Koefisien & $\begin{array}{c}\text { Standar } \\
\text { Error }\end{array}$ & $\begin{array}{c}\mathrm{t}- \\
\text { Statistik }\end{array}$ & Keterangan \\
\hline $\begin{array}{l}\text { Persepsi kegunaan } \rightarrow \text { Sikap berperilaku } \\
\text { pengguna }\end{array}$ & 0,354 & 0,123 & 2,886 & Signifikan \\
$\begin{array}{l}\text { Kemudahan penggunaan } \rightarrow \text { Sikap } \\
\text { berperilaku pengguna }\end{array}$ & 0,573 & 0,132 & 4,352 & Signifikan \\
$\begin{array}{l}\text { Kemudahan penggunaan } \rightarrow \text { Rasa Manfaat } \\
\text { Norma subjektif } \rightarrow \text { Minat Berperilaku }\end{array}$ & 0,668 & 0,078 & 8.577 & Signifikan \\
$\begin{array}{l}\text { Sikap berperilaku pengguna } \rightarrow \text { Minat } \\
\text { Perilaku }\end{array}$ & 0,231 & 0,112 & 2,121 & Signifikan \\
\hline
\end{tabular}

Sumber: Data diolah, 2018

Hipotesis ketiga $\left(\mathrm{H}_{3}\right)$ menduga kemudahan penggunaan berpengaruh positif pada rasa manfaat. Hasil pengujian menunjukkan bahwa $\mathrm{H}_{3}: \beta_{3}>0$, artinya kemudahan penggunaan berpengaruh positif pada rasa manfaat. Hasil analisis menunjukkan bahwa nilai koefisien 0,668 mempunyai besaran $\mathrm{t}$ hitung 8,577. Pada tingkat level of significance $\alpha=5$ persen maka t hitung lebih besar dari t tabel kritis 1,98. Artinya kemudahan penggunaan berpengaruh positif pada rasa manfaat.

Hipotesis keempat $\left(\mathrm{H}_{4}\right)$ menduga morma subyektif berpengaruh pada minat menggunakan. Hasil pengujian menunjukkan bahwa $\mathrm{H}_{5}: \beta_{5}>0$, artinya Sikap berperilaku penggunaberpengaruh positif pada minat menggunakan. Hasil analisis menunjukkan bahwa nilai koefisien 0,231 mempunyai besaran t hitung 2,121. Pada tingkat level of significance $\alpha=5$ persen maka thitung lebih besar dari t tabel kritis 1,98. Artinya norma subyektif berpengaruh positif pada minat menggunakan.

Hipotesis kelima $\left(\mathrm{H}_{5}\right)$ menduga Sikap berperilaku pengguna berpengaruh pada minat menggunakan. Hasil pengujian menunjukkan bahwa $\mathrm{H}_{4}: \beta_{4}>0$, artinya Sikap berperilaku pengguna berpengaruh positif pada minat menggunakan. Hasil analisis menunjukkan bahwa nilai koefisien 0,720 mempunyai besaran $\mathrm{t}$ hitung 6,423. Pada tingkat level of significance $\alpha=5$ persen maka t hitung lebih besar dari t tabel kritis 1,98. Artinya Sikap berperilaku pengguna berpengaruh positif pada minat menggunakan.

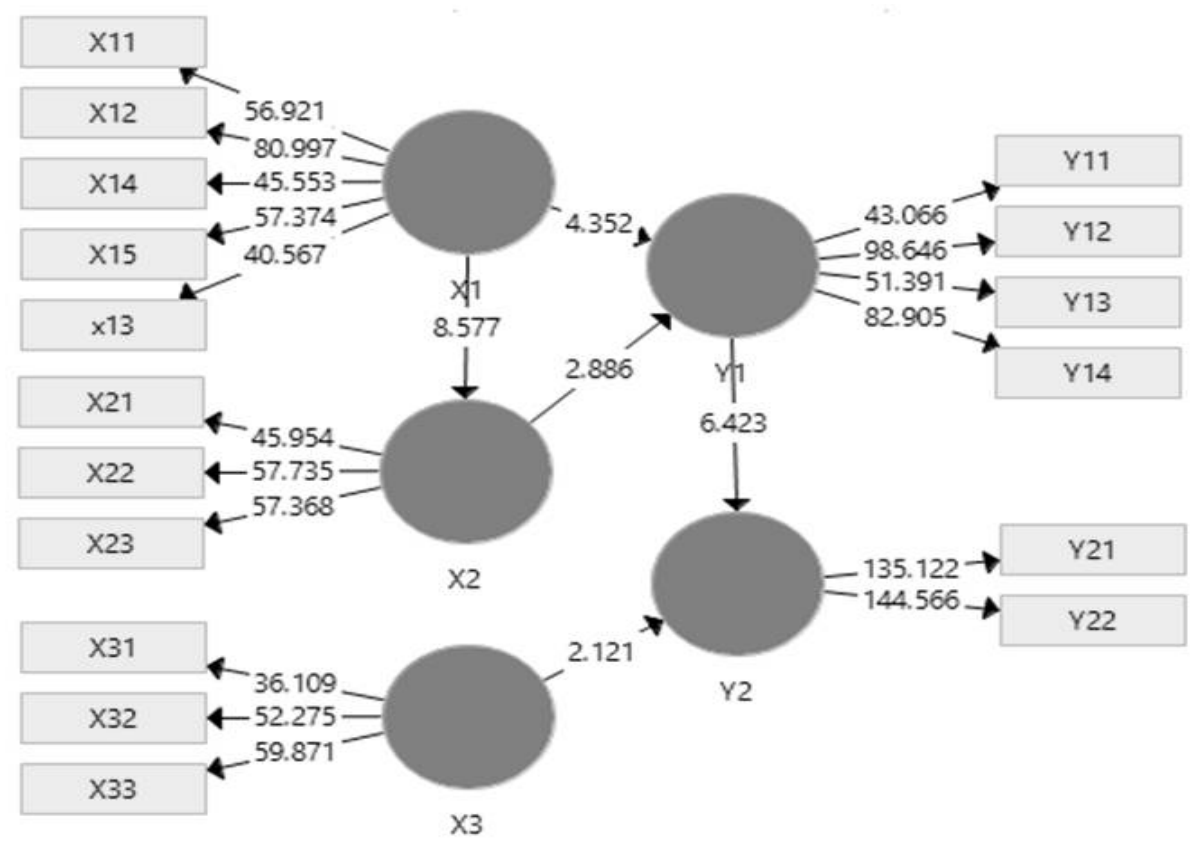

Sumber: Data diolah, 2018

\section{Gambar 3. Hasil Pengujian Hipotesis}


Hasil analisis menunjukkan bahwa semakin tinggi persepsi pengguna bahwa e-billing memiliki kegunaan atau rasa manfaat maka dapat meningkatkan minat wajib pajak orang pribadi menggunakan $e$-billing. Hal tersebut menunjukkan bahwa system e-billing memberikan manfaat bagi WP seperti meningkatkan performa penyetoran pajak yang sebelumnya menggunakan Surat Setoran Pajak (SSP) yang konvensional menjadi e-billling dan mampu meminimalisir kesalahan input data wajib pajak seperti NPWP, kode akun, jenis setoran, tahun pajak maupun terbilang pada jumlah yang akan dibayar.

Kegunaan e-billing lainnya mampu meningkatkan efektivitas penyetoran pajak dimana penyetoran pajak menjadi lebih mudah dan cepat bisa tanpa melalui teller untuk melakukan pembayaran bisa langsung melalui internet banking. Penyetoran pajak bisa dilakukan dimanapun dan kapanpun tidak seperti penggunaan SSP yang hanya bisa dibayar pada hari kerja saja sesuai dengan Bank/Kantor Pos membuka layanan. Jika memilih pembayaran melalui teller pun para wajib pajak tidak perlu menunggu lama karena teller hanya melakukan satu inputan yakni ID billing saja menggantikan sistem manual yang sebelumnya teller menginput 6 jenis input data wajib pajak yang akan dibayar sehingga $e$-billing memberikan kegunaan bagi efektivitas penyetoran dengan lebih cepat. Apabila individu menganggap bahwa suatu sistem teknologi memiliki manfaat atau kegunaan maka hal tersebut akan mendorong individu untuk menggunakan teknologi tersebut. Hasil tersebut sejalan dengan pandangan teori TAM yang menjelaskan bahwa penerimaan individual terhadap penggunaan sistem teknologi informasi. TAM digunakan untuk memprediksi penerimaan pengguna pada teknologi salah satunya berdasarkan persepsi kegunaan. Hasil penelitian ini sejalan dengan penelitian yang dilakukan oleh Davis (1989), Szajna (1996) dan Igbaria et al. (1997) yang menemukan hal yang sama bahwa persepsi kegunaan atau rasa manfaat berpengaruh pada penggunaan aktual.

Semakin baik persepsi WPOP bahwa $e$-billing memiliki kemudahan penggunaan maka dapat meningkatkan penggunaan $e$-billing. Hal tersebut menunjukkan bahwa para pengguna menganggap sistem e-billing mudah dipelajari, mudah mengaplikasikan sistem e-billing dan e-billing digunakan rutin dapat membuat penggunanya terampil menggunakan system tersebut. Kemudahan penggunaan suatu sistem akan mempengaruhi tingkat penggunaan sistem tersebut. Apabila pengguna menginterpretasikan bahwa sistem mudah digunakan maka penggunaan sistem akan tercapai. Hasil tersebut sejalan dengan pandangan teori TAM yang merupakan teori yang menjelaskan penerimaan individual terhadap penggunaan sistem teknologi informasi salah satunya berdasarkan persepsi kemudahan. Hasil penelitian ini sejalan dengan penelitian yang dilakukan oleh Laihad (2013) dan Nurhasanah et al. (2015) yang menemukan hasil bahwa persepsi kemudahan penggunaan berpengaruh pada penggunaan suatu sistem.

Keputusan individu untuk menerima suatu teknologi sistem informasi merupakan tindakan sadar yang dapat dijelaskan dan diprediksi oleh minat perilakunya. TAM berargumentasi bahwa penerimaan individual terhadap sistem teknologi informasi ditentukan oleh perceived of usefulness dan perceived easy of used. Kemudahan penggunaan memengaruhi rasa manfaat. Akan tetapi, tidak sebaliknya. Pemakai sistem akan menggunakan sistem tersebut apabila dirasakan bermanfaat, baik sistem itu mudah digunakan atau tidak mudah digunakan. Sistem yang sulit digunakan akan tetap digunakan jika pemakainya merasa bahwa sistem mudah digunakan. Pemakaian sistem dapat bersifat sukarela atau bersifat wajib. Pemakaian $e$ billing bagi WPOP bersifat sukarela sehingga dapat merefleksikan persepsi dan perasaan masing-masing individual dan menjadi penentu yang baik dari kesulitan sistem.

Hasil analisis menunjukkan bahwa kemudahan penggunaan berpengaruh positif pada persepsi rasa manfaat penggunaan e-billing. Hasil ini menunjukkan bahwa hipotesis penelitian didukung. Penelitian pengaruh persepsi kemudahaan penggunaan terhadap persepsi manfaat telah dilakukan oleh Bashir \& Madhavaiah (2015) menunjukkan bahwa terdapat pengaruh yang positif dan signifikan persepsi kemudahaan penggunaan terhadap persepsi manfaat atau persepsi kegunaan. Hasil yang berbeda ditunjukan oleh penelitian yang dilakukan oleh Chen \& Tsai (2007), menyatakan bahwa persepsi kemudahaan penggunaan tidak berpengaruh signifikan terhadap minat penggunaan aplikasi mobile tourisme.

Sikap berperilaku pengguna berpengaruh positif pada minat menggunakan e-billing. Hasil ini mendukung hipotesis yang menyatakan bahwa sikap berperilaku pengguna berpengaruh positif pada minat menggunakan $e$-billing. Hal ini sesuai dengan theory of planned behavior dan technology acceptance 
model. Sikap wajib pajak berperilaku menggunakan $e$-billing dapat meningkatkan niat wajib pajak orang pribadi menggunakan $e-$ billing untuk menyetorkan pajaknya.

Hasil analisis juga menunjukkan bahwa norma subyektif berpengaruh pada minat wajib pajak orang pribadi menggunakan $e$-billing. Hasil ini mendukung hipotesis yang menyatakan bahwa norma subyektif berpengaruh pada minat wajib pajak orang pribadi menggunakan e-billing. Norma subyektif adalah sejauh mana seseorang memiliki motivasi untuk mengikuti pandangan orang lain. Wajib pajak orang pribadi merasakan bahwa dalam menggunakan $e$ billing, mengikuti pandangan orang lain, teman, keluarga, kerabat menggunakan e-billing dalam membayar pajak.

Ajzen (1988) mendefinisikan bahwa norma subjektif sebagai persepsi seseorang mengenai tekanan sosial untuk melakukan atau tidak melakukan perilaku. Norma subjektif mengacu pada penilaian subjektif individu mengenai preferensi orang lain dan dukungan (support) atas suatu perilaku. Penelitian sebelumnya yang dilakukan oleh Mas'ud (2012) menunjukkan bahwa norma subjektif berpengaruh positif terhadap minat nasabah menggunakan automatic teller machine yang merupakan sebuah alat elektronik yang melayani nasabah bank untuk mengambil uang dan mengecek rekening tabungan mereka tanpa perlu dilayani oleh seorang teller manusia. Susanto (2011) menyatakan bahwa norma subyektif juga memegang peranan penting dalam memengaruhi niat wajib pajak orang pribadi dalam menggunakan e-filling. Wajib pajak berminat menggunakan $e$-filling karena mendengarkan saran dari teman atau orang lain. Berdasarkan hal tersebut wajib pajak perlu sosialisasi yang lebih intensif agar wajib pajak orang pribadi berminat menggunakan $e$ billing.

\section{SIMPULAN}

Berdasarkan hasil analisis dapat disimpulkan bahwa persepsi kegunaan berpengaruh positif pada sikap berperilaku wajib pajak orang peribadi (WPOP) di Bali dalam menggunakan e-billing. Semakin bermanfaat dirasakan oleh WPOP dalam menggunakan $e$-billing menyebabkan sikap berperilaku WPOP dalam penggunaan e-billing semakin baik. Kemudahan penggunaan e-billing berpengaruh positif pada sikap berperilaku WPOP dalam menggunakan e-billing. Semakin mudah menggunakan $e$-billing menyebabkan sikap berperilaku WPOP dalam menggunakan e-billing semakin meningkat.

Kemudahan penggunaan berpengaruh positif pada persepsi kegunaan dalam menggunakan $e$ billing. Kemudahan penggunaan menimbulkan rasa manfaat semakin meningkat. Sikap berperilaku berpengaruh positif pada minat WPOP dalam menggunakan $e$-billing. Sikap terhadap perilaku dan norma subyektif berpengaruh positif pada penggunaan e-billing. Hal ini berarti WP yang memiliki sikap positif seperti: merasa nyaman, senang dan menikmati menggunakan e-billing cenderung untuk selalu menggunakan e-billing system dibandingkan dengan pengguna yang memiliki sikap negatif. Norma subyektif berpengaruh positif pada minat WPOP dalam penggunaan $e$-billing, WPOP menggunakan $e$-billing karena pengaruh dari teman dan orang yang berpengaruh.

Keterbatasan penelitian ini adalah pengambilan sampel hanya pada satu tempat daerah saja yaitu provinsi Bali. Bagi peneliti berikutnya dapat memperluas daerah penelitian dengan menyebarkan kuesioner ke provinsi lain di luar provinsi Bali. Penelitian ini dalam memperediksi minat berperilaku penggunaan $e$-billing hanya menggunakan faktor internal dari WPOP. Penelitian selanjutnya diharapkan menambahkan variabel yang bersumber dari eksternal individu, misalnya jaminan keamanan.

\section{REFERENSI}

Adam, D. A., Nelson, R. R., \& Todd, P. A. (1992). Accounting Conservatism and Valuation of Accounting Numbers: Evidence of the FelthamOhlson (1996) Model. MIS Quarterly, 2(16), 227-250.

Ajzen, I. (1988). Attitudes, Personality, \& Behavior. Dorsey Press, Chicago

Ajzen, I., \& Fishbein, M. (1970). The prediction of behavior from attitudinal and normative beliefs. Journal of Experimental Social Psychology, 6, 466-487. https://doi.org/10.1016/00221031(70)90057-0

Ajzen, I., \& Fishbein, M. (1980). Understanding attitudes and Predicting Social Behavior. NJ: Prentice Hall. New Jersey.

Arthana, Y. W., \& Rukhviyanti, N. (2015). Pengaruh Minat Individu Terhadap Penggunaan Mobile Banking (M-Banking): Model Kombinasi Technology Acceptance Model (TAM) dan Theory Of Planned Behaviour (TPB). Jurnal Informasi, 7(1). 
Bashir, I., \& Madhavaiah, C. (2015). Consumer attitude and behavioural intention towards Internet banking adoption in India. Journal of Indian Business Research, 7(1), 67-102.

Chandrarin, G. (2018). Metode Riset Akuntansi Pendekatan Kuantitatif. Jakarta:Salemba Empat.

Chen, C., \& Tsai, D. (2007). How Destination Image and evaluative factors affect behavioral intentions. Tourism Management.

Chin, W. W., \& Todd, P. A. (1995). On the Use, Usefulness, and Ease of Use of Structural Equation Modeling in MIS Research: A Note of Caution. MIS Quarterly, 19, 237-246.

Davis, F. D. (1993). User Acceptance of Information Technology: System Characteristics, User Perceptions and Behavioral Impacts. International Journal of Man-Machine Studies, 38(3), 475-487.

Davis, F. D. (1989). Perceived Usefulness, Perceived Ease of Use, and User Acceptance of Information Technology. MIS Quarterly, 13(3), 319-340.

Goodhue, D. L., \& Thompson, R. L. (1995). Task Technology Fit and Individual Performance. MIS Quarterly, 19(2), 213-236.

Hair, J.F., W.C. Black, B.J. Babin, R.E. anderson, R.L.Tatham, (2006). Multivariate Data Analysis, 6 Ed., New Jersey : Prentice Hall

Igbaria, M., Zinatelli, N., Cragg, P., \& Cavaye, A. L. M. (1997). Personal Computing Acceptance Factor in Small Firms: A Structural Equatiion Model. MIS Quarterly, 21(3), 279-305.

Jogiyanto. (2007). Sistem Informasi Keperilakuan. Yogyakarta: Andi Offset.

Laihad, R. C. Y. (2013). Pengaruh Perilaku Wajib Pajak terhadap Penggunaan E-Filing Wajib Pajak di Kota Manado. Jurnal EMBA, 1(3), 44-51.

Mas'ud, M. H. (2012). Pengaruh Sikap, NormaNorma Subyektif dan Kontrol Perilaku Yang Dipersepsikan Nasabah Bank Terhadap Keinginan Untuk Menggunakan Automatic Teller Machine (Atm) Bank Bca di Kota Malang. Jurnal Manjemen Dan Akuntansi, 1(28), 13-28.

Nasri, W., \& Lanouar, C. (2012). Factors Affecting the Adoption of Internet Banking in Tunisia: Theory of Acceptance Model and Theory of Planned Behavior. Journal of High Technlogy Management Research, 23, 1-14.
Nurhasanah, Firmansyah, \& Novrida. (2015). Pengaruh Persepsi Wajib Pajak Orang Pribadi terhadap Penggunaan E-Filing di KPP Pratama Palembang Ilir Barat. Jurnal Akuntanika, 1(1).

Nysveen, H., Pedersen, P. E., \& Thorbjørnsen, H. (2005). Explaining intention to use mobile chat services: Moderating effects of gender. Journal of Consumer Marketing, 22(5), 247-256.

Peterson, J. L. (2003). Oral and Maxillofacial Surgery. C.V Mosby Company.

Rahyuda, K. (2016). Metode Penelitian Bisnis. Udayana University Press.

Ratnaningrum, L. P. R. A. (2013). Aplikasi Model TAM Terhadap Pengguna Layanan Internet Banking di Kota Denpasar. Tesis. Denpasar: Universitas Udayana.

Rysaka, N., Saleh, C., \& Rengu, S. (2013). Penerapan Sistem Elektronik dalam Pelayanan Perpajakan (Studi pada Kantor Pelayanan Pajak Pratama Malang Utara). Jurusan Akuntansi Publik (JAP), 2(3), 420-425.

Saad, N. (2014). Tax Complexity and Tax Compliance: Taxpayers View. Procedia-Social and Behavioral Sciences, 109, 1069-1075.

Sanjaya, I.P.S.(2005) Pengaruh Rasa Manfaat dan Kemudahan Terhadap Minat Berperilaku (Behavioral Intention) Para Mahasiswa dan Mahasiswi dalam Penggunaan Internet. Kinerja, 9, (2), 113-122

Segars, A. H., \& Grover, V. (1993). Re-examining Perceived Ease of Use and Usefulness: A Confirmatory Factor Analysis. MIS Quarterly, 18(4), 517-525.

Sekaran, U. (2006). Research Method for Business. John Wiley \& Sons, Inc, 160.

Seni, N.N.A \& Ratnadi, N.M.D., (2017) Theory of Planned Behavior Untuk Memprediksi Niat Berinvestasi. E-Journal Ekonomi dan Bisnis Universitas Udayana. 6 (12), 4043-4068.

Solimun. (2002). Multivariate Analysis Structural Equation Modelling (SEM) Lisrel dan Amos. Fakultas MIPA, Universitas Brawijaya.

Subramanian, G. H. (1994). A Replication of Perceived Usefulness and Perceived Ease of Use Measurement. Decision Sciences, 25(6), 863-874.

Susanti, L. (2017). Pengaruh Perilaku Wajib Pajak Orang Pribadi pada Pengunaan E-Billing di KPP Pratama Denpasar Barat. Tesis. Denpasar: Universitas Udayana. 
Susanto, N. (2011). Analisis Perilaku Wajib Pajak terhadap Penerapan Sistem E-Filling Direktorat Jenderal Pajak.Tesis. Universitas Indonesia.

Szajna, B. (1996). Empirical Evaluation of The Revised Technology Acceptance Model. Informs Pubs Online Management System, 42(1), 85-92.

Taylor, S., \& Todd, P. A. (1995). Understanding Information Technology Usage: A Test of Competing Models. Information System Research, 6, 144-176.

Venkatesh, V., \& Moris, M. G. (2000). Why Don't Men Ever Stop to Ask for Directions? Gender, Social Influence, and Their Role in Technology
Acceptance and Usage Behavior. MIS Quarterly, 24(1).

Venkatesh, V., Morris, M. G., \& Ackerman, P. L. (2000). A Longitudinal Field Investigation of Gender Differences in Individual Technology Adoption Decision-Making Processes, 83(1), 33-60. https://doi.org/10.1006/obhd.2000.2896

Zadeh, S. ., Ayub, A. F. ., Mahmud, R., \& Daud, S. . (2014). Behavior Intention to Use of Learning Management System among Malaysian PreService Teachers: A Confirmatory Factor Analysis. International Journal of Education \& Literacy Studies, 2(1), 29-39. 